\title{
HDM2 Inhibitor HDM201
}

National Cancer Institute

\section{Source}

National Cancer Institute. HDM2 Inhibitor HDM201. NCI Thesaurus. Code C116325.

An orally bioavailable human double minute 2 homolog (HDM2) inhibitor with potential antineoplastic activity. HDM2 inhibitor HDM201 inhibits the binding of the HDM2 protein to the transcriptional activation domain of the tumor suppressor protein p53. By preventing this HDM2-p53 interaction, the proteasome-mediated enzymatic degradation of p53 is inhibited, which may result in the restoration of both p53 signaling and p53-mediated induction of tumor cell apoptosis. HDM2, a zinc finger protein and negative regulator of the p53 pathway, is often overexpressed in cancer cells and has been implicated in cancer cell proliferation and survival. 